\title{
The Tendency of Revenue and Levies Contributions to the PAD Jayapura before and after the Law No.
} 28 of 2009

\author{
FahruddinPasolo \\ Indonesia \\ fachrudin_pasolo@yahoo.com
}

\begin{abstract}
This study aims to determine the tendency of growth of tax revenu elevies, the contribution PAD Jayapura city before and after the Law 28 Year 2009. The research method is done through quantitative analysis using financial ratio analysis techniques Jayapura city government. The resultis an average contribution of taxes to PAD both before and after the implementation of Law No.28 of 2009 showed an increase but the contribution levy decreased. However, the contribution of PAD to Total Revenue Region (TPD) showed an increase(rising).
\end{abstract}

Keywords: Taxes, levies and Contributions PAD

\section{Introduction}

During the 15 years of traveling the implementation of fiscal decentralization was not yet able to create local financial independence. Based on data from the Regional Financial Information System (MoF) Ministry of Finance, it can be argued that until 2013, the average cost of areas in Indonesia is largely dominated by the high contribution coming from the fund balance, which reached an average of $80 \%$ of total revenues area. While local revenue is an indicator of local financial independence on average only account for $18 \%$ of total regional income. While the basic requirements for successful implementation of decentralization are adequate sources of revenue to fund spending responsibilities allocated to local governments. For that, the area was given the authority to collect taxes and levies (local taxing power). Granting authority to impose taxes and levies are intended to provide services in accordance with the ability of its people. Levy taxation authority and the latter has been regulated in Law Number 28 Year 2009 on Local Taxes and Levies Act Daerah. Undang is a substitute Act No. 18 of 1997 on Regional Taxes and Levies, as amended by Act No. 34 of 2000, which effectively came into force on January 1,2010. The Act is a strategic step to strengthen the decentralization is more ideal.

Compared to the previous regulation that Act No. 34 of 2000, under Act number 28 of 2009 on Local Taxes and Levies there is a new charge that the collection of taxes and levies new, broadening the tax base and levy, as well as flexibility in setting tax rates (Adji et al, 2013). In addition, Act Local Taxes and Levies were recently also introduced a system of closed lists, where the regional government can not collect taxes and levies beyond those stipulated in the Act. Type a new tax for the district / city is the inclusion of two types, namely central tax Tax on Acquisition of Land and Building (BPHTB) and the Land and Building Tax for Rural and Urban sector (PBB P2) as the local tax district tax / kota.Ini a change in supporting decentralization in line with the general understanding and international experience shows that property taxes are better left to daerahsebagai source of income district / city level (Ananda, et al, 2012). In addition to the transfer of the two types of tax into the tax center district / city, there is also the transfer of the provincial tax Tax Groundwater were also transferred into the tax district / city. New taxes to the district / city the latter is a tax Swallow's Nest. Of the levy, there are four (4) types of levies districts / cities of the new levies Tera / Tera Birthday, Levy Control Tower Telecommunication Service Fees for Education and Fisheries Business Permits.

The expansion of the tax base of the district / city according to Law No. 28 of 2009 contained in the hotel tax, restaurant tax, entertainment tax, advertisement tax, and street lighting tax. Hotel diperluas tax base by supporting the inclusion of all services provided by the hotel such as sports facilities, entertainment, internet, phone, fax, copier, washing, ironing and transport as objects Taxes. Tax base expanded dengandimasukkannya restaurant food services and catering as part of the object restaurant tax. 
Entertainment Tax base expanded with the inclusion of a beauty contest, bodybuilding, and the like; exhibitions, circus, acrobatics and magic; the game of golf and bowling; racetrack and race a motor vehicle; as well as reflections and fitness center as part of the Entertainment Tax object. Advertisement tax base was expanded with the inclusion of floating billboards as part of the object pajak. Basis street lighting tax was expanded with the inclusion of the use of electricity generated themselves as part of the tax object. Furthermore levy which was expanded base was Permits Disorders that optimize imposition, so it covers a wide range of levies relating to the environment that has been collected, such as Permits Disposal of Wastewater, Levy EIA, as well as levies the Health and Safety at Work (Abdullah, 2009) . Discretionary policy through Law No. 28 of 2009 to the local government be interesting to study in the city of Jayapura, given the Jayapura City is one city in the province of Papua, which relies solely PAD acquisition of the services sector, especially of Taxes and Levies

\section{Literature Riview}

Santoso and Rahayu (2005) mention that the PAD as a reception area reflects the degree of local autonomy. The larger the area the more revenue it is able to implement fiscal decentralization and reduced dependence on central government. However, the policies of fiscal decentralization that is, not necessarily be able to establish the independence of the region quickly. Funds raise for the implementation of regional development according to Wrihatnolo and Dwidjoyowiyoto (2007) can be obtained in the form of (1) taxes, (2) charges, (3) non-tax revenue, and (4) public company earnings. Of the four forms of income, can be divided into two (2) major parts, namely taxes and levies daerah. Pajak is mandatory dues paid by the individual or entity to regions without asking for any compensation based on the legislation in force and only used for finance the implementation of government and regional development (Erly, 2005). While Retribution is a levy for the payment of certain services or request permission by the local government in order to meet the needs of any person or entity (Siahaan, 2005). Tax and Retribution is a central component in the acquisition of revenue (PAD).

Landiyanto (2005) in his research on the Financial Performance and Strategies of Urban Development in the Era of Regional Autonomy in Surabaya found that reliance on the central area is still high because not optimal acceptance of PAD and not optimal revenue / profit enterprises. Until now the potential of local revenues are still focused on the acquisition of taxes and levies. It took a long time to build self-reliance in the area of finance budget spending minimal region in meeting the needs of personnel expense. Until now the region's dependence on the central government through equalization funds is still quite large. Kawung (2008) in his research found that the financial capacity of the province of North Sulawesi is still low, amounting to 30.66\% of the local revenue, which means that the role of PAD is still lacking and needs to be improved. The description above shows that the financial capacity of the area represented local revenue (PAD) still focuses on the components of taxes and levies.

\section{Methodology}

The approach usedin this study isthatitsapproachposivitismeandrationalism. The research was conductedthrougha survey oftaxesand leviesin Jayapurabeforeandafter theenactment ofAct28of 2009. The data were analyzedthroughquantitative analysis usingfinancial ratioanalysis techniquesof local government. The procedure isobservedfrom the tendencyortrendof financial ratiosJayapura citybefore and afterthe enactmentof LawNo. 28 of2009.There are threekinds offinancial ratiosJayapura cityin that periodwill be countedandobserved, namely:

Growth Ratio Regional Taxes, Levies, andPAD

Where:

$$
\text { Tax Growth }=\frac{\operatorname{Tax}_{t}-\operatorname{Tax}_{t-1}}{\operatorname{Tax}_{t-1}} \times 100 \%
$$

$\operatorname{Tax}_{\mathrm{t}}$

$=$ Realization of thetaxyeart

$\operatorname{Tax}_{\mathrm{t}-1}$

$=$ Realization of thetaxyeart -1

Formula Levy growth ratio is as follows. 
Where:

$$
\text { Levy Growth }=\frac{\operatorname{Levy}_{t}-\operatorname{Levy}_{t-1}}{L e v y_{t-1}} \times 100 \%
$$

Levy $_{\mathrm{t}} \quad=$ Realization Levyint

Levy $\mathrm{t}_{\mathrm{t}-1}=$ Realization Levyint-1

Formula Growth PAD ratioisas follows.

Where :

$$
P A D \text { Growth }=\frac{P A D_{t}-P A D_{t-1}}{P A D_{t-1}} \times 100 \%
$$

$\mathrm{PAD}_{\mathrm{t}}=$ Realization PADin the year of $\mathrm{t}$

$\mathrm{PAD}_{\mathrm{t}-1}=$ RealizationPAD in the year oft-1

a.Effectiveness Ratio Regional Taxes, Levies, andPAD

$$
\begin{aligned}
\text { Eeffectiveness Ratio } & =\frac{\text { Realization } \text { Tax revenues }}{\text { Target } \text { Tax revenue }} 100 \% \\
\text { Effectiveness Retribution Ratio } & =\frac{\text { Realization retribution revenues }}{\text { Target } \text { Retrubution revenue }} \times 100 \% \\
\text { Effectiveness PAD Ratio } & =\frac{\text { Realization } P A D \text { Revenue }}{\text { Target } P A D \text { Revenue }} \times 100 \%
\end{aligned}
$$

b. Regional Taxes Contributions ratio to PAD, Retribution against PAD and PAD toTotal Revenue Region

$$
\begin{aligned}
& \text { Texes Contribution } \text { Cf }_{t} \text { oftal taxes }=\frac{\text { Tax Revenue }_{t}^{i}}{\text { Total Tax REvenue }_{t}} \times 100 \% \\
& \text { Taxes Contribution }_{t}^{i} \text { of PAD }=\frac{\text { Tax Revenue }_{t}^{i}}{\text { Total PAD revenue }_{t}} \times 100 \% \\
& \text { Contribution Retribution }{ }_{t}^{i} \text { of Total Retribution }=\frac{\text { Retribution Revenue }_{t}^{i}}{\text { Total Retribution Revenue }_{t}} \times 100 \% \\
& \text { Contribution Retribution }_{t}^{i} \text { of PAD }=\frac{P A D \text { Revenue }_{t}^{i}}{\text { Total PAD Revenue }_{t}} \times 100 \%
\end{aligned}
$$

\section{Results and Discussion}

The third trend of financial ratios Jayapura City area in the period before and after the decentralization of taxes and charges through the implementation of Law No.28 of 2009are summarized in the following table. 
Table 1: Trend Growth Ratio, Effectiveness and Contributions Tax/Levy/PAD Jayapura At Period Before and After the Implementation of Law No. 28 Year 2009

\begin{tabular}{llll}
\hline Ratio & $\begin{array}{l}\text { Before } \\
\text { Implementation UU } \\
\text { No 28 Th 2009 (\%) }\end{array}$ & $\begin{array}{l}\text { After Implementation } \\
\text { No 28 Th 2009 (\%) }\end{array}$ & UU \\
& 30,43 & 37,84 & Ridends \\
\hline Average growth in Tax & 16,64 & 8,88 & Down \\
Average growth Levy & 22,44 & 24,56 & Ride \\
Average growt h of PAD & 110,31 & 112,14 & Ride \\
Average Effectiveness Tax & 103,40 & 108,08 & Down \\
$\begin{array}{ll}\text { Average Effectiveness of Retribution } \\
\text { Rata-rata Efektivitas PAD }\end{array}$ & 112,83 & 110,04 & Ride \\
$\begin{array}{l}\text { Average contributions Tax of PAD } \\
\text { Average Contributions retribution }\end{array}$ & 39,53 & 59,74 & Ride \\
$\begin{array}{l}\text { PAD } \\
\text { Average Contributions PAD of TPD }\end{array}$ & 47,08 & 30,89 & Down \\
\hline
\end{tabular}

Source :Research result

Overview of financial ratios Jayapura City area above shows that there are some conditions that are not supposed to. Some of these conditions are reduction in growth rate levies significantly in the period after taxes and levies decentralization through the implementation of Law No. 28 of 2009. Furthermore,a decrease inthe ratio ofPADeffectivenessanddecreasing the ratio ofcontributionlevies toPADin the period aftertaxes andleviesdecentralizationthroughthe implementation of LawNo. 28 of2009.in addition,the increase inthe ratio ofthe growth and effectiveness oflocal taxandrevenuein the periodafterthe implementation of LawNo. 28of 2009 which isnot optimal. The onlything thatwas encouragingwasthe increase inthe ratio ofcontributionof local taxes toPADsignificantlyin the period aftertaxes andleviesdecentralizationthroughthe implementation of LawNo.28 of 2009.

Various phenomena are not in accordance with the conditions that should happen if the Jayapura City Government take advantage of opportunities in the decentralization of central government tax revenues and charges through the enactment of Law No. 28 of 2009 is. As well as research conducted by Adji, et al (2013) in analyzing the seven districts / cities as samples in Indonesia. The result of Law No. 28 of 2009 has been able to increase local fiscal capacity on the sample area. This is seen in several indicators such as growth in revenue, growth in the realization of local taxes, taxes per capita, the ratio of tax to GDP AHB, the ratio of tax to $\mathrm{PAD}$, the ratio of revenue to the total revenue, the ratio of revenue to total regional spending, and the ratio of revenue to GDP AHB in regional samples increased in 2011. It is suspected there is a possibility Command Jayapura City is not optimal menafat chances of the Act sebagaiman described by Rondinelli and Cheema (1983), that the benefits of the policy a decentralization, among others: (1) open the chance of developing the capabilities of administration greater for local government institutions and private provincial and district / city, (2) decentralization can make the administration to be more flexible, innovative and creative, (3) the decentralization of development planning and management functions allow local leaders to determine the services and facilities more effectively with the community, 4) decentralization may increase service delivery of public goods and services, and at a lower cost.

\section{Conclusion and Recommendations}

The conclusionsofthis studyis the averagecontribution oftaxesto PADboth before andafterthe implementation ofLaw No.28 of 2009showed an increasebut the contributionlevydecreased. However,the contributionof PAD toTotalRevenueRegion(TPD) showed an increase(rising). Thereforethe Jayapura City Governmentneeds tobe more creativeandtake advantage of opportunitiesto improve the effectivenesscorridorprovided bythe Act,in order togainmoreoptimalPADJayapura City in supporting theRegional OriginalRevenue(PAD).

\section{References}


Abdullah, S. (2009). Law No. 28/2009 on Regional Taxesand Levies, syukriy. wordpress.com/10.17.2009/points-setting-laws-local-tax-and-levy-area

Adji, A., Eddy, S., Candra, F. A. \& Hamid, P. (2013). Evaluation of the Implementation of Law No. 28 of 2009 on Local Taxes and Levies and Its Effect on Regional Income, Statement of the Ministry of Finance Sector Assistance Team Fiscal Decentralization. Jakarta.

Ananda, C. F., Eddy, S. \& Hamid, P. (2012). Analisa Dampak Pengalihan Pemungutan BPHTB Ke Daerah Terhadap Kondisi Fiskal Daerah, Laporan Tim Asistensi Kementerian Keuangan Bidang Desentralisasi Fiskal. Jakarta.

Erly, S. (2005). Hukum Pajak, Edisi Ketiga, Jakarta: Salemba Empat.

Kawung, G. M. V. (2008). Analisis Kemampuan Keuangan dan Ketergantungan Daerah Provinsi Sulawesi Utara pada Era Otonomi Daerah.Jurnal FORMAS, 1(4).

Landiyanto, E. A. (2005). Financial Performance and Urban Development Strategy in the Era of Regional Autonomy; Case Study Surabaya, Cures Working Paper 05/01, January 2005.

Law No. 28 of 2009 on Regional Taxes and Levies

Law Number 32 Year 2004 on Regional Government

Siahaan, P. M. (2005). Pajak Daerah dan Retribusi Daerah Jakarta: PT. Rajagrafindo Persada,

Santoso \& Rahayu. (2005). Analisis Pendapatan Asli Daerah (PAD) dan Faktor-Faktor Yang Mempengaruhinya Dalam Upaya Pelaksanaan Otonomi Daerah di Kabupaten Kediri. Dinamika Pembangunan, 2(1).

Wrihatnolo, R. R. \& Dwidjowijoto, R. N. (2007). Manajemen Pemberdayaan, Elex Media Komputindo gramedia, Jakarta. 